NBER WORKING PAPER SERIES

\title{
A MODEL OF TRADE AND EXCHANGE RATE PROJECTIONS
}

Hannu Halttunen

Dennis Warner

Working Paper No. $\underline{389}$

\section{NATIONAL BUREAU OF ECONOMIC RESEARCH 1050 Massachusetts Avenue Cambridge MA 02138}

August 1979

The models presented in this paper were developed by the authors under the direction of William Branson while at OECD Project Interfutures and were extended during the NBER Summer Institute for International Economics. The results of the simulations are somewhat different from those contained in the final report of Project Interfutures and do not reflect the official views of Project Interfutures. The research reported here is part of the NBER's research program in International Studies. Any opinions expressed are those of the authors and not those of the National Bureau of Economic Research. 
A MODEL OF TRADE AND EXCIIANGE RATE PROJECTIONS

\section{ABSTRACT}

This paper develops and applies a model of world trade and exchange rates to analyze dynamic interaction of the current account and exchange rate. The model is designed to concentrate on the determination of trade flows, prices and exchange rates for the OECD member countries but it also covers oil exporting countries, other developing countries and Centrally Planned Economies.

The model contains exchange rate equations, based on the asset market approach, for mafor OECD countries and adjustable pegging rules for small OECD countries and for non-oil LDCs. These provide the link from asset accumulation through the current account to the exchange rate. With the integration of exchange rate equations into the trade model, it can be used to analyze outcomes of different exchange rate regimes and alternative growth prospects in the OECD area.

Simulation results indicate that the model produces a smooth and slow adjustment process for exchange rates and current accounts. They also show that with the higher growth target for an individual country large current account deficits may occur or large changes in real exchange rates are needed to reach the external equilibrium.

Hannu Halttunen Bank of Finland Research Department P.0. Box 160 SF-00101 Helsink1 FINLAND
Dennis Warner

Department of Economics Michigan State UnIversity E. Lansing, MI 48824

517/355-7756 


\section{Introduction}

This paper develops and applies a model of world trade and exchange rates to analyze dynamic interaction of the current account and exchange rate. The model is designed to concentrate on the determination of trade flows, prices and exchange rates for the OECD member countries but it also covers oil exporting countries, other developing countries and Centrally Planned Economies.

The model contains exchange rate equations, based on the asset market approach, for major OECD countries and adjustable pegging rules for smal1 OECD countries and for non-oil LDCs. These provide the link from asset accumulation through the current account to the exchange rate. With the integration of exchange rate equations into the trade model, it can be used to analyze outcomes of different exchange rate regimes and alternative growth prospects in the OECD area.

Simulation results indicate that the model produces a smooth and slow adjustment process for exchange rates and current accounts. They also show that with the higher growth target for an individual country large current account deficits may occur or large changes in real exchange rates are needed to reach the external equilibrium.

It must be, however, emphasized that the projected changes in market shares and exchange rates reflect the growth assumptions and the introduction of different exchange rate regimes as well as historical income and price elasticities in international trade. That is why they are conditional and should not be interpreted as forecasts of future develpments of trade flows and exchange rates.

The paths for potential and actual GDP in the OECD countries are generated by a sma11 model which projects output based on growth in productivity and labor force and which projects investment requirements for ten major OECO countries. 
Table 1 illustrates a few results of a model simulation. For this run the growth rate of actual German GDP was increased by on percentage point for the 15-year run. Germany, of course, runs a larger current account deficit and its exchange rate depreciates and its inflation rate increases. Strong effects are seen for the other European countries: all appreciate and experience reduced inflation rates. While the smaller countries gain market shares and improve their current accounts, the larger countries lose market shares and have worsened current accounts. The non-European countries are little affected. The macro model for each country takes as inputs the following time series; male and female working age population, level of armed forces, "full employment" level of the unemployment rate, sector-specific equilibrium capitaloutput ratio, depreciation rates, and shares of total output. Using these time series as inputs into a small econometric model for each country, levels of gross domestic product, employment, capital stocks and investment requirements by sector are generated for the 1976 to 1990 period. Different projections may be made by either altering the time series inputs or by providing different values for the parameter estimates used in the equations.

The international model determines equilibrium trade flows, prices, and exchange rates for the 26 regions. The GDP results from the individual macro models are used as inputs into import-demand equations for three types of traded goods: non-oil merchandise, oil, and non-factor services. Import demand in each category is a function of domestic GDP, the import price, and the domestic GDP deflator.

Thw GDP deflator depends on an exogenously-specified production-cost index and import prices. Export prices are a function of the domestic price 
TABLE 1

Changes Caused by Increased German Growth

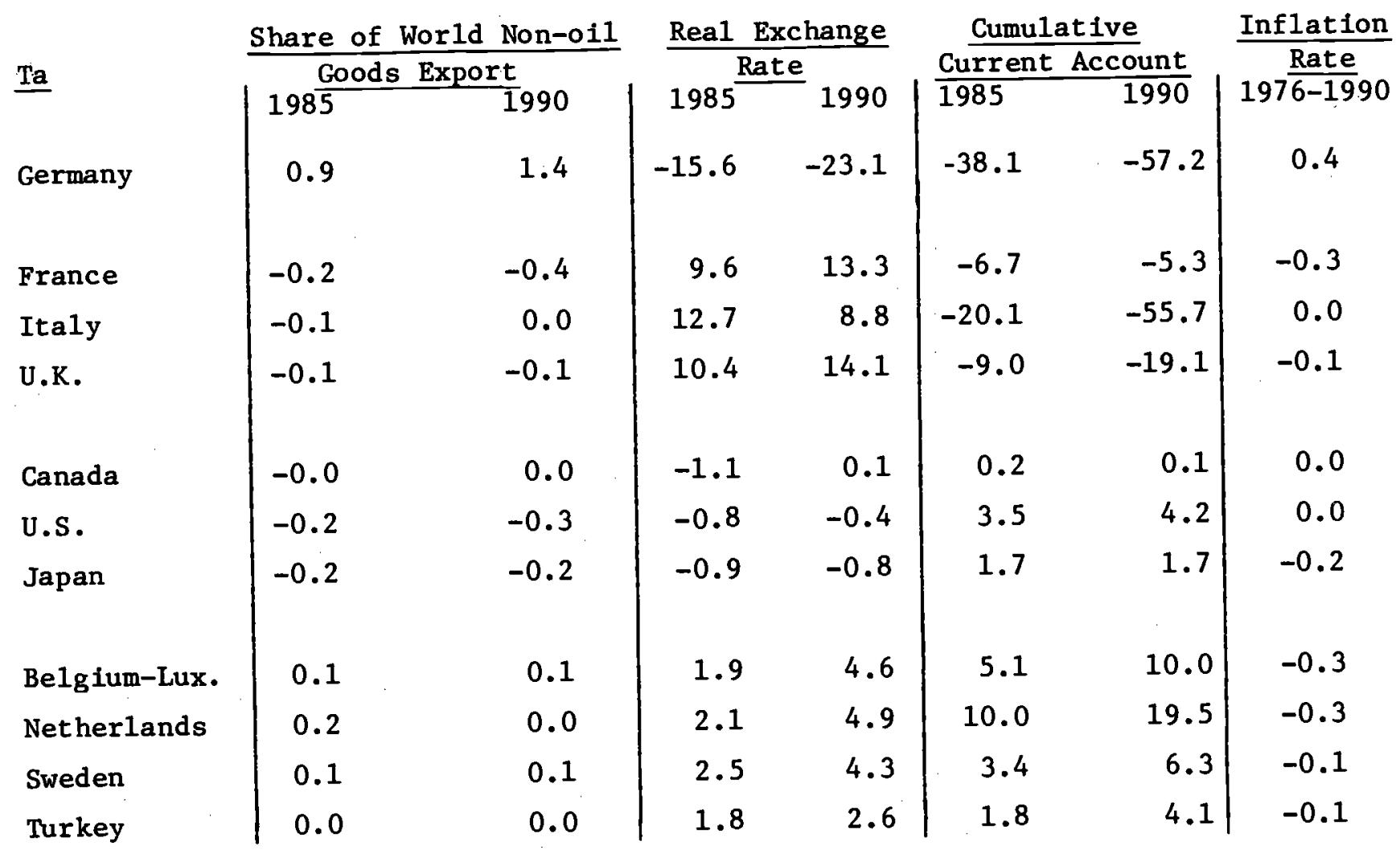

Note: More complete results are given later in the paper. 
as well as all other export prices. The import prices are determined by a trade-weighted average of export prices, and the exchange rate.

Bilateral trade flows are determined by import demands and a bilateral import-share matrix. The share matrix is adjusted every period to reflect changes in relative export prices and exchange rates.

Several options for exchange rate determination are built into the model. The first is to allow exchange rates to adjust to give Balance of Payments flow-equilibrium for all regions. The second option is for fixed exchange rates; treating changes in international reserves as a residual item to balance each region's international payments. The third option is to solve for major countries dollar exchange rate from empirical asset market equation. Then the payments are balanced by additions to or subtractions from the region's net foreign assets. Countries for which the exchange rate equations have been estimated are Canada, France, Germany (Federal Republic), Italy, Japan, and the U.K. The small countries exchanged rates are either fixed (OPEC, the LDC's, and the Centrally-Planned Region) or are determined by a rule which pegs each region's currency to a weighted average of its trading partner's currencies.

The remainder of the paper is divided into three parts. Section II explains the simple procedure used to project growth in real and potential output. Section III covers projections for investment requirements in ten major OECD countries. Section IV gives a brief explanation of the trade and exchange rate model and presents results from several simulations.

\section{Projections}

Potential output projections were performed for twenty-one OECD nations. ${ }^{1}$ The following paragraphs are a step-by-step description of the output projections.

Labor Force

To provide a numerical basis for analysis of the long-run aggregate growth

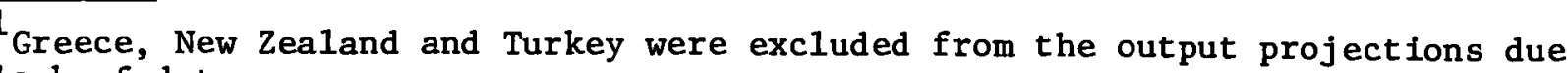
to lack of data. 
prospects, we have begun with the projections of underlying demographic change, 1.e. the growth in working age population (15-64 years old), and assumptions regarding the evolution of labour force participation rates. These described the potential supply of labour resources avallable in each country. The projections of workIng age population are drawn from country responses to the INrERFUTORES' questionnaire or Onited Nations' projections on the basis of internal analysis. Participation rates of the civilian labour force are based on national projections and ILO estimates. Table 2 contains historical and projected growth rates of working-age population for twenty-one countries

TABLE 2

Average Annual Grouth Rates 의

Total Working Age Population

\begin{tabular}{|l|c|c|c|c|c|}
\hline & $65-75$ & $75-80$ & $80-85$ & $85-90$ & $75-90$ \\
Australia & 2.1 & 1.8 & 1.2 & 1.5 & 1.6 \\
Austria & 0.0 & 1.2 & 0.6 & 0.1 & 0.6 \\
Belgium-Iux & 0.4 & 0.6 & 0.7 & 0.0 & 0.4 \\
Canada & 2.5 & 2.1 & 1.4 & 1.0 & 1.5 \\
Denmark & 0.5 & 0.4 & 0.5 & 0.1 & 0.4 \\
Finland & 0.7 & 0.4 & 0.3 & 0.0 & 0.2 \\
France & 0.9 & 0.7 & 1.1 & 0.4 & 0.7 \\
Germany & 0.4 & 0.4 & 0.9 & -0.5 & 0.3 \\
Iceland & 1.8 & 1.5 & 1.4 & 1.3 & 1.4 \\
Ireland & 0.8 & 1.3 & 1.2 & 1.2 & 1.3 \\
Italy & 0.6 & 0.5 & 0.7 & 0.2 & 0.5 \\
Japan & 1.2 & 1.0 & 0.9 & 0.8 & 0.9 \\
Netherlands & 1.3 & 0.9 & 0.7 & 0.1 & 0.6 \\
Norway & 0.6 & 0.5 & 0.4 & 0.3 & 0.4 \\
Portugal & 1.4 & 0.8 & 0.7 & 0.5 & 0.6 \\
Spain & 0.8 & 1.1 & 1.0 & 0.6 & 0.9 \\
Sweden & 0.3 & 0.0 & 0.2 & 0.0 & 0.0 \\
Switzerland & 0.9 & 0.2 & 0.4 & 0.1 & 0.2 \\
O.r. & 0.0 & 0.5 & 0.5 & 0.0 & 0.3 \\
D.S. & 1.7 & 1.4 & 0.9 & 0.5 & 0.9 \\
& & & & & \\
\hline
\end{tabular}




\section{Employment}

The labor force is equal to the level of working age population multiplied by the participation rate. From this value a constant level of armed forces Is subtracted to arrive at the civilian labor force.

For each country, a "potential" or "full-employment" unemployment rate 18 used to arrive at potential employment. These potential unemployment rates are drawn from INTERFUTURES Internal studies. Table 3 displays the assumed potential unemployment rates and projected growth rates for potential employment.

The projections show that the higher growth rates for employment will be In Austral1a, Canada, Iceland, Ireland, The Netherlands, and the U.S. Low rates of growth are projected for Finliand, Norway, Sweden, Switzerland, and the U.K.

TABLE 3

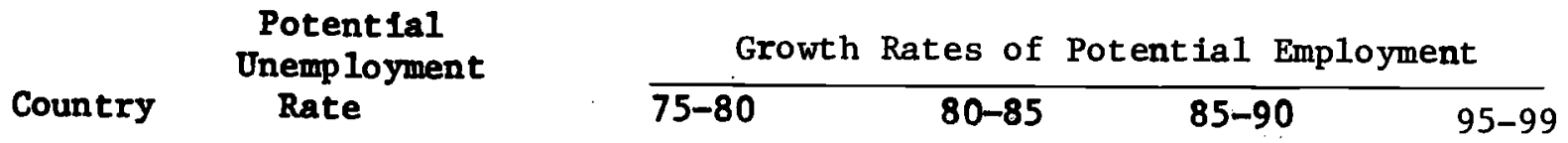

$\begin{array}{llrrrr}\text { Australla } & 2.0 & 2.1 & 1.2 & 1.1 & 1.5 \\ \text { Austrla } & 2.2 & 0.7 & 0.4 & 0.0 & 0.4 \\ \text { Belglum-Lux } & 3.5 & 1.1 & 0.6 & -0.1 & 0.6 \\ \text { Ganada } & 4.5 & 2.4 & 1.2 & 0.8 & 1.5 \\ \text { Denmark } & 4.5 & 0.7 & 0.7 & 0.3 & 0.6 \\ \text { Finland } & 3.3 & -0.1 & 0.6 & 0.3 & 0.3 \\ \text { France } & 2.1 & 0.8 & 0.9 & 0.1 & 0.6 \\ \text { Germany } & 1.3 & 0.9 & 0.9 & -0.5 & 0.4 \\ \text { Iceland } & 0.4 & 0.5 & 0.0 & 1.8 & 1.3 \\ \text { Ireland } & 5.0 & 1.5 & 1.0 & 1.3 & 1.3 \\ \text { Italy } & 2.5 & 0.6 & 0.8 & 0.1 & 0.5 \\ \text { Japan } & 0.9 & 0.9 & 0.7 & 0.6 & 0.7 \\ \text { Netherland } & 1.3 & 1.5 & 1.2 & 0.6 & 1.1 \\ \text { Norway } & 1.9 & 0.5 & 0.4 & 0.0 & 0.3 \\ \text { Portugal } & 0.0 * & 0.7 & 0.4 & 0.3 & 0.5 \\ \text { Spaln } & 3.0 & 1.1 & 0.8 & 0.5 & 0.8 \\ \text { Sweden } & 1.5 & 0.2 & 0.1 & 0.0 & 0.1 \\ \text { Switzerland } & 0.0 & 0.5 & 0.5 & 0.1 & 0.3 \\ \text { U.K. } & 1.6 & 0.5 & 0.3 & -0.2 & 0.2 \\ \text { O.S. } & 4.5 & 2.5 & 0.9 & 0.5 & 1.3\end{array}$


Productivity

Historfcal trend growth rates of output per man-year was taken from estimates of simple labor-demand equations for the twenty countries. These regressions were run using data from 1960 through 1975. Due to the very simple specification of the labor-demand equation, the estimated growth rate of output per man year Includes both a measure of technical progress and any trend in the wage/rent ratio.

For 1975 to 1980 , the trend value was used to calculate potential productivity. For the remaining years, the growth rates were changed to represent a convergence of OECD productivity levels and growth rates. We assumed that productivity levels would not surpass those of the $\mathrm{O.S}$. and that the productivity rate of growth would equal that of the 0.5 . when the levels were equal. For each country, we assumed that the convergence would occur between the year 2000 (for Japan) and 2025 (for the lowest productivity countries). These assumptions imply the path of producifity growth rates given in Table 4 (See page 8 ). The low productivity countrles will have high rates of growth and conversely for the high-productivity countries.

\section{Potential Output}

Potentlal output is equal to full-employment times the level of potential productivity. The projected growth rates are shown In Table 5. (See page 9). The rates of growth for Austria, the Netherlands, and Portugal seem implausibly high. The Implausibility lies in the paths of productivity growth rate assumed for each.

Reaching Potential Output

As of 1978, none of the twenty countries were at potentlal output. Most of the countries have unemployment rates higher than the "full-employment" level 
TABLE 4

Potential Productivity Growth Rates

\begin{tabular}{|c|c|c|c|c|c|}
\hline Country & $\begin{array}{c}1975^{\star} \\
\text { Potential } \\
\text { Productivity }\end{array}$ & $1975-1980$ & $\begin{array}{r}\mathrm{Pr} \\
\mathrm{Gr} \\
80-85\end{array}$ & $\begin{array}{l}\text { tlons } \\
\text { Rates } \\
\quad 85-90\end{array}$ & $75-90$ \\
\hline $\begin{array}{l}\text { Australia } \\
\text { Austria } \\
\text { Belglum-Lux } \\
\text { Canada } \\
\text { Denmark } \\
\text { Finland } \\
\text { France } \\
\text { Germany } \\
\text { Iceland } \\
\text { Ireland } \\
\text { Italy } \\
\text { Japan } \\
\text { Netherland } \\
\text { Norway } \\
\text { Portugal } \\
\text { Spain } \\
\text { Sweden } \\
\text { Switzerland } \\
\text { U.R. } \\
\text { U.S. }\end{array}$ & $\begin{array}{r}8.1 \\
6.2 \\
8.4 \\
11.3 \\
7.7 \\
6.0 \\
8.4 \\
8.8 \\
6.8 \\
5.0 \\
5.5 \\
5.4 \\
8.6 \\
9.2 \\
2.8 \\
3.9 \\
9.5 \\
8.4 \\
5.7 \\
13.4\end{array}$ & $\begin{array}{l}3.2 \\
5.5 \\
4.1 \\
2.1 \\
3.3 \\
4.8 \\
4.4 \\
4.5 \\
2.3 \\
4.3 \\
5.7 \\
6.7 \\
5.2 \\
4.1 \\
7.4 \\
5.5 \\
2.6 \\
3.3 \\
2.8 \\
1.8\end{array}$ & $\begin{array}{l}3.2 \\
3.9 \\
3.9 \\
2.2 \\
3.3 \\
4.6 \\
4.1 \\
4.1 \\
2.8 \\
4.4 \\
5.3 \\
6.0 \\
4.5 \\
3.7 \\
7.0 \\
5.4 \\
2.7 \\
3.3 \\
3.2 \\
1.8\end{array}$ & $\begin{array}{l}3.2 \\
3.5 \\
3.5 \\
2.3 \\
3.3 \\
4.3 \\
3.7 \\
3.6 \\
3.3 \\
4.4 \\
4.8 \\
5.3 \\
3.7 \\
3.3 \\
6.5 \\
5.3 \\
2.7 \\
3.2 \\
3.7 \\
1.8\end{array}$ & $\begin{array}{l}3.2 \\
5.0 \\
3.8 \\
2.2 \\
3.3 \\
4.6 \\
4.1 \\
4.0 \\
2.8 \\
4.4 \\
5.3 \\
6.0 \\
4.5 \\
3.7 \\
7.0 \\
5.4 \\
2.7 \\
3.3 \\
3.2 \\
1.8\end{array}$ \\
\hline
\end{tabular}

and have productivity levels well below the estimated potential level.

For the particular profection shown here, we arbitrarily assumed that both productivity and employment reach their potential levels in 2000 . Both values were IInearly interpolated between their actual 1978 value and the potential levels in 2000. 
TABLE 5

Average Annual Growth Rates of Potential Output

\begin{tabular}{|c|c|c|c|c|}
\hline Country & $75-80$ & $80-85$ & $85-90$ & $75-90$ \\
\hline $\begin{array}{l}\text { Australia } \\
\text { Austria } \\
\text { Belgium } \\
\text { Canada } \\
\text { Denmark } \\
\text { Finland } \\
\text { France } \\
\text { Germany } \\
\text { Iceland } \\
\text { Ireland } \\
\text { Italy } \\
\text { Japan } \\
\text { Netherlands } \\
\text { Norway } \\
\text { Portugal } \\
\text { Spain } \\
\text { Sweden } \\
\text { Switzerland } \\
\text { U.K. } \\
\text { U.S. }\end{array}$ & $\begin{array}{l}5.4 \\
6.4 \\
5.3 \\
4.6 \\
4.0 \\
4.7 \\
5.3 \\
5.4 \\
5.6 \\
5.7 \\
6.3 \\
7.6 \\
6.8 \\
4.7 \\
8.2 \\
6.7 \\
2.7 \\
3.9 \\
3.3 \\
4.4\end{array}$ & $\begin{array}{l}4.5 \\
5.7 \\
4.5 \\
3.4 \\
4.0 \\
5.3 \\
5.0 \\
5.0 \\
4.1 \\
5.6 \\
6.2 \\
6.8 \\
5.8 \\
4.1 \\
7.5 \\
6.3 \\
2.8 \\
3.8 \\
3.6 \\
2.7\end{array}$ & $\begin{array}{l}4.4 \\
4.6 \\
3.4 \\
3.1 \\
3.6 \\
4.6 \\
3.8 \\
3.0 \\
4.5 \\
5.8 \\
4.9 \\
6.0 \\
4.3 \\
3.4 \\
6.8 \\
5.8 \\
2.7 \\
3.4 \\
3.5 \\
2.4\end{array}$ & $\begin{array}{l}4.8 \\
5.6 \\
4.4 \\
3.7 \\
3.9 \\
4.8 \\
4.7 \\
4.5 \\
4.7 \\
5.7 \\
5.8 \\
6.8 \\
5.6 \\
4.0 \\
7.5 \\
6.3 \\
2.8 \\
3.7 \\
3.5 \\
3.2\end{array}$ \\
\hline
\end{tabular}

Table 5 (See page 10) displays the 1978 ratios of actual to potential for both productivity and employment in the first two columns. The third column contains the percentage shortfall of actual from potential GDP in 1978 . The final colum gives the average growth rate of GDP from 1978 to 1990 . Note that the required growth rates are very high for several countries; espectally Austria, Ireland, Italy, Spain, and Portugal. Th1s may point out the unreasonableness of the assumed productivity growth paths. It 18 also of interest that the shortfall of GDP from potential is almost entirely due to a shortfall in productivity: the shortfall in employment plays a relatively minor role. 
TABLE 6

\begin{tabular}{|c|c|c|c|c|}
\hline Country & $\begin{array}{c}1978 \\
\text { Ratio of } \\
\text { Actual to Potential } \\
\text { Productivity }\end{array}$ & $\begin{array}{c}1978 \\
\text { Ratio of } \\
\text { Actual to } \\
\text { Potential Employment }\end{array}$ & $\begin{array}{c}1978 \\
\text { \& GDP Gap }\end{array}$ & $\begin{array}{c}\text { Growth Rate } \\
\text { of GDP } \\
1978-1990\end{array}$ \\
\hline $\begin{array}{l}\text { Australia } \\
\text { Austria } \\
\text { Belgium } \\
\text { Canada } \\
\text { Denmark } \\
\text { Finland } \\
\text { France } \\
\text { Germany } \\
\text { Iceland } \\
\text { Ireland } \\
\text { Italy } \\
\text { Japan } \\
\text { Netherlands } \\
\text { Norway } \\
\text { Portugal } \\
\text { Spain } \\
\text { Sweden } \\
\text { Switzerland } \\
\text { U.K. } \\
\text { U.S. }\end{array}$ & $\begin{array}{r}.86 \\
.84 \\
.85 \\
1.00 \\
.89 \\
.86 \\
.93 \\
.89 \\
.93 \\
.83 \\
.94 \\
.86 \\
.85 \\
.89 \\
1.08 \\
.88 \\
.92 \\
.81 \\
.97 \\
.95\end{array}$ & $\begin{array}{c}.96 \\
.99 \\
.97 \\
.98 \\
.99 \\
1.00 \\
.97 \\
.96 \\
1.00 \\
.99 \\
.98 \\
1.00 \\
.97 \\
1.00 \\
1.00 * \\
.98 \\
1.00 \\
1.00 \\
.96 \\
.98\end{array}$ & $\begin{array}{r}15.6 \\
15.4 \\
16.5 \\
1.2 \\
11.8 \\
14.8 \\
9.0 \\
14.3 \\
10.4 \\
17.9 \\
7.4 \\
14.4 \\
17.4 \\
10.4 \\
-8.0 \\
13.5 \\
7.7 \\
18.7 \\
7.0 \\
6.7\end{array}$ & $\begin{array}{l}5.3 \\
6.2 \\
5.0 \\
3.4 \\
4.5 \\
5.9 \\
5.0 \\
5.1 \\
4.9 \\
6.7 \\
6.1 \\
7.3 \\
6.3 \\
4.4 \\
6.9 \\
6.9 \\
3.2 \\
4.6 \\
3.9 \\
3.1\end{array}$ \\
\hline
\end{tabular}

As mentloned earlier Portugal has no unemployment rate in this model and is always at "full employment."

III. Investment Projections

III. A. Countries and Sectors

This section presents a simple quantitative framework for analysis and projections of fixed Investment needs for a sample of OECD countries consistent with the output projection described in the previous section. Given the output development, a central question 18 what level of capltal stock and thus which flow of gross fixed capital Information are implied by such growth prospects. We could not do an all-inclusive study of capital requirements in the OECD area due to the data problems and time constraint; our intention 18 to cover enough of the Important countrles so as to be confident that any serfous prospective problems or policy 1ssues would come to our notice. 
The projections span the years 1979 to 1990 and the countrles included in the exercise are:

1. Belgium

2. Canada

3. France

4. Germany (Federal Republic of)

5. Italy
6. Japan

7. Netherlands

8. Sweden

9. Dnited Ringdom

10. Dnited States

For each of these countries the same methodology was used to project investment requirements. Although the nature of capital requirements 18 similar in most of the OECD countries the problems in Southern European labour surplus countries may be different from the problems of industrialised countries In our sample and thus called for a different approach from ours. In order to allow for different sectoral capital intensitles each economy was divided Into four sectors. These are as follows:

1. Agriculture.

2. Industry (mining and quarrying, manufacturing, electricity, gas and water, construction).

3. Private services (Including housing).

4. Public services.

The following set of equations was designed to carry out projections.

\section{B. The Model}

Assuming the existence of a stable relationship between desired capital stock (K) and output ( $Y$ ) and a constant depreclation rate of capital ( $\delta$ ), we can derive the following set of relationships between full employment output $(\bar{Y})$, full employment capital stock $(\bar{K})$ and gross investment (I).

(1)

(4)

$$
\overline{\mathrm{k}}_{1}=\hat{k}_{1} \cdot \nabla_{1} \cdot \overline{\bar{y}}
$$

$$
G_{1}=\bar{k}_{1}-R_{1}
$$

$$
R_{1}=\bar{K}_{1}-\frac{G_{1}(1979)}{T}(T-t)
$$

$$
I_{1}=\Delta R_{1}+\delta_{1} R_{1}
$$

$1=1,2,3,4$

$$
1=1,2,3,4
$$

$1=1,2,3,4$

$1=1,2,3,4$ 
Equation (1) projects the full employment stock $(\overline{\bar{k}})$ of sector 1 given the full employment capital output ratio $(\hat{k})$, sector 1 's value added share $\left(v_{1}\right)$ and full employment GDP $(\bar{Y})$. Note that we have applied the same value-added share projections to both potential and actual GDP. Equation (2) gives the gap $\left(G_{1}\right)$ between full employment capital stock and actual capital stock. The actual capital stock appraoches the full employment path according to equation (3), where the gap is closed during eleven years time of recovery $(T=11, t=0, \ldots 11)$. Equation (4) simply expresses grosg investment needs in each sector as a sum of net Investment and replacement investment, which is a constant fraction of capital stock. All the stock varlables are beginning of perlod figures. The total investment and capital needs and the whole economy's capital gap are computed by adding up the relevant variables. All the variables are measured In constant 1975 U.S. dollars.

III C. Derivation and Profections of the Parameters in the Model

The parameters to be estimated in the model are equilibrium (full employment) capital output ratios $\left(k_{1}\right)$ and depreciation rates $\left(\delta_{1}\right)$ in each sector as well as value-added shares $\left(v_{1}\right)$ of each sector.

Full employment capital-output ratio

We assume that in 1973 the economies in our sample were in equilibrium in the sense that there was just enough fixed capital in each sector to fully employ the labour force given the development of relative prices of capital and Iabour. This assumption is based on the fact that 1973 was a cyclical peak in most of these econonles. More critical than the cholce of the full employment year may be the assumption that in this year the labour-capital mix was optimal given development of wage-rental rat1o. Nevertheless this assumption allows us to calculate full employment capital output ratios which are also "desired" or equilibrium ratios, if there are no underlying forces to change capital-labour-mix. These capital-output ratios by country and by sector are shown in Table $7.1 /$ 
TABLE 7: Capital-output ratios in 1973

\begin{tabular}{|c|c|c|c|c|c|}
\hline & Agriculture & Industry & $\begin{array}{l}\text { Private } \\
\text { Services }\end{array}$ & $\begin{array}{l}\text { Public } \\
\text { Services }\end{array}$ & $\begin{array}{l}\text { Total } \\
\text { Economy }\end{array}$ \\
\hline $\begin{array}{l}\text { 1. Belglum- } \\
\text { Lusxembourg }\end{array}$ & 2.2 & 2.1 & 3.1 & 2.8 & 2.6 \\
\hline 2. Canada & 5.0 & 2.5 & 3.1 & 3.7 & 3.0 \\
\hline 3. France & 2.5 & 2.1 & 3.3 & 3.5 & 2.7 \\
\hline 4. Germany & 5.6 & \multicolumn{2}{|c|}{4.2} & 2.7 & 4.0 \\
\hline 5. Italy & 2.0 & 1.8 & 3.4 & 1.8 & 2.4 \\
\hline 6. Japan & 1.9 & 2.2 & \multicolumn{2}{|c|}{3.1} & 2.7 \\
\hline 7. Netherlands & 1.8 & 2.3 & 3.5 & 4.4 & 3.0 \\
\hline 8. Sweden & 5.6 & 2.9 & 7.8 & 4.1 & 4.9 \\
\hline 9. Onited Kingdom & 3.3 & 2.4 & 3.1 & 3.5 & 2.9 \\
\hline 10. United States & 3.1 & 2.1 & 3.3 & 3.2 & 2.8 \\
\hline
\end{tabular}

Source: See text.

\section{Depreclation rates}

The long-term model of the United Nations Economic Commission for Burope (the exogenous varlables of the SEM Model: Past trends and projected values 1977) provides estimates for sectoral depreclation rates (agriculture, industry, private services, excluding residential and public services) by European sub-reglons (North, West and South Burope). These were applied to corresponding Individual thuropean countries in our sample. Depreclation rates for the Onited States were taken to be arithmetic means of Buropean rates. In public ser-

I/ The main data source for the sectoral capital stock series is a Rand Corporation Study by Steln and Lee (1977) except for Sweden. For Sweden the capital stock data are avallable in the Swedish national income account statistics. Since capital stock data by sectors are very scarce and there are large differences between the varlous sources, we wanted to exploit one common source (Rand Study) as much as possible in order to provide comparabllity between countrles. Also resources avallable for the study did not allow a more careful and refined treatment of the data. Consequently, the data and the projection results are sultable only to evaluate general trands and directions of changes. Sectoral output data for all countries come from OECD national income accounts except for Streden where corresponding Swedish national sources were used. Different sources of data for Sweden may also explain its highest capital-output ratio in the sample. 
vices the depreciation rate for the United States was expected to be above turopean average and was taken to be 3 per cent per year. The same flgures were also applied to Canada and Japan except that in the case of Japan the depreciation rate in agriculture was chosen to be the same as in "North Europe." The values of $0 . S$. depreclation rates were checked against the information provided by another ECE source (ECE: Capital Stock: Assessment of Past and Current Trends by Sectors and Countries, 1977), an OECD study, Measurement of cap1tal (Ward 1976), and a J.S. growth model (H1ckman and Coen, 1976). These showed large varlations between different sources and gave little indication as to which direction to adjust our estimates.

\begin{tabular}{|l|c|c|c|c|}
\hline \multicolumn{1}{|c|}{ TABLE 8: Depreciation Rates } \\
\hline & Agriculture & Industry & $\begin{array}{c}\text { Private } \\
\text { Services }\end{array}$ & $\begin{array}{c}\text { Public } \\
\text { Services }\end{array}$ \\
\cline { 2 - 5 } 1. Belglum- & 3.4 & 4.4 & 2.1 & 1.7 \\
Lurembourg & 4.5 & 5.0 & 2.2 & 3.0 \\
2. Canada & 6.4 & 5.4 & 2.0 & 2.7 \\
3. France & 6.4 & & 3.0 & 2.7 \\
4. Germany & 6.4 & 5.4 & 1.5 & 2.7 \\
5. Italy & 3.4 & 5.0 & 2.0 & 3.0 \\
6. Japan & 3.4 & 4.4 & 1.8 & 1.7 \\
7. Nether1ands & 3.4 & 4.4 & 1.8 & 1.7 \\
8. Sweden & 6.4 & 5.4 & 2.0 & 2.7 \\
9. United Kingdom & 4.5 & 5.0 & 2.0 & 3.0 \\
10. Cnited States & & & & \\
\hline
\end{tabular}

\section{Source: See text.}

Depreclation rates (Continued)

Depreciation rate estimates for private service sector including housing were obtained by welghting together depreclation rates for private services excluding housing, and the depreclation rate for housing which was fixed to be 1.5 per cent for all countrles except Italy, and the United Kingdom. For these countrles a lower value of 1.0 per cent was used on the basis of the average age estimates of bulldings and structures glven in Ward (1976). The relevant weights are relative capital stock shares in 1973. 
Value added shares

The projections of the compostion of output were obtained mainly by extrapolating the past trends. Value-added shares in each economy were projected up to 1985 and then kept at this level. This is more or less arbitary, but nevertheless allows us to have some kind of idea of future capital needs during the recovery period with structural cahnge.

Projected value-added share changes imply a generalized decrease in the value-added share of agriculture. Industry's share is increasing in all countries except in the United states where it is slightly decreasing. In general, the projected increase in industry's share is larger the higher the growth rate of total GDP during the recovery period. Government's share is assumed to stay more or less constant. The residual 1tem - private services - shows a moderate decifne In most of the countrles. In the absence of any better information, value added share projections were applied to generate both potentlal and actual sectoral output paths.

\section{D. Generation of the capital gap at the beginning of 1979}

Given the potential GDP projections described in section II to generate sectoral full employment capital stocks in each economy. The actual sectoral capital stock figures at the beginning of 1979 were obtained by cumulating investment on 1973 stocks allowing for capital retirement using the sectoral depreciation rates given in Table 8 (See page 14 ). In the absence of any quantitiative information, we did not try to take into account possible increased scrapping proposed on the hypothesis that large shifts in relative prices after the oil crisis made some of the existing capital obsolete. Thus, our actual capital stock numbers in this sense can be interpreted to represent a kind of upper boundary and thus they may underestimate the actual capital gaps. Sectoral gross investment numbers come from OECD national income accounts or from OECD Economic outlook for the period 1973-1978. Where investment in real terms was not available on sectoral level nominal investment shares are applied to split total real fixed investment which was available for each country. Given these capital stocks, capital gaps are defined as the difference between full employment capital stock and the actual 
one. These gaps are shown in Table 9. (below) for Industry and for total economy. The capital gaps thus depend on the growth of full employment capital stock and the investment flow (given depreclation rate), out of which two the latter 18 more important in most cases.

TABLE 9: Capital gaps in the beginning of 1979

\begin{tabular}{|l|r|r|r|r|}
\hline \multirow{2}{*}{} & \multicolumn{2}{|c|}{ Whole Economy } & \multicolumn{2}{c|}{ Industry } \\
\cline { 2 - 5 } 1. Belgium-Luxembourg & \multicolumn{1}{|c|}{ B } & Billion 1975 US\$ & 8 & Billion 1975 US\$ \\
\cline { 2 - 5 } 2. Canada & 1.4 & 2.9 & 15.4 & 10.9 \\
3. France & 2.3 & 13.5 & 8.8 & 16.0 \\
4. Germany* a/ & .9 & 10.0 & 19.9 & 73.0 \\
5. Italy & 16.2 & 378.0 & 18.5 & 384.0 \\
6. Japan & 1.5 & 8.0 & 8.7 & 14.0 \\
7. Netherlands & -1.4 & -28.0 & 26.1 & 193.0 \\
8. Sweden & 12.4 & 42.3 & 25.0 & 27.0 \\
9. United Kingdom & 5.8 & 21.7 & 9.6 & 9.0 \\
10. United States & 1.5 & 11.0 & 15.5 & 43.0 \\
& 7.7 & 399.0 & 4.7 & 59.0 \\
\hline
\end{tabular}

a/ For Germany Industry also includes Private Services. Source: See text.

The results indicate varations in the extent of the present capital shortfall across the countrles in our sample but also large differences within each country across sectors. At the aggregate level, the gaps are Insignificant in the cases of Belgium, Canada, France, Italy, Japan, and the United States. At the other end of the 11st are the Netherlands, with Sweden falling in between. In the case of Canada, the explanation 1s obvlously the increase in energy investment projects. In France, the decline in private sector Investment was compensated by increasing public investment In electricity, and In Sweden the Increase was delayed unt1l 1975 by stimulative fiscal incentives. 
There are good reasons to expect that the housing stock estimate in 1979 Is too low due to the high depreclation rate used in the Rand Corporation study for housing. This implies that we possibly underestimate the aggregate capital-output ratio in the service sector including housing which in turn means a downward blas in capital requirement estimates. In order to have some Idea of the quantitative effects of different capital-output ratios, we Inerensed the full employment capital-output ratio in the private-service sector by 20 per cent and carrled out the needed calculations. The results show that there 1s now a capital shortfall in each country. Also, at aggregate level, Increases in the gap vary between two and four percentage points but In general, the ranking of the countries has not changed. This calculation Indicates that on the basis of the present analysis, it is difficult to estimate whether at the aggregate level the capital stock in the "boundary countrles" (Belglum, Canada, France, Italy, Japan, and the UnIted RIngdom) Is sufficient fully to utilise the labor force.

At the Industry level, there seems to be a capital shortfall in each country. The relative gap exceeds the IImit of ten per cent in all other cases except Canada, Italy, Sweden and the United States. Japan and the Netherlands are now the problem countries with capital gaps over 25 per cent. There 18 one obvious reason for the differences between gap estimates at the aggregate level and at the Industry level: the inclusion of the housing sector into private services.

III. E. Investment Returns

The estimates of the current capital gap and the growth of full employment capital stock give a growth path for future capital requirements. This path Implies a stream of gross fixed investment consistent with 1t. Table 10 (See page 17) shows such Investment as a percentage of total GDP (In Industry's case investment as a percentage of industry's value added.) 
TABLE 10: Investment-GDP Shares, \%

\begin{tabular}{|c|c|c|c|c|c|}
\hline & & \multicolumn{2}{|c|}{$\begin{array}{l}\text { Whole Economy; } \\
\text { Investment } \\
\text { GDP ratio, \& }\end{array}$} & \multicolumn{2}{|c|}{$\begin{array}{l}\text { Industry } \\
\text { Investment-industry } \\
\text { value-added ratio, } 8\end{array}$} \\
\hline & & $1975-1978$ & $1979-1990$ & $1975-1978$ & $1979-1990$ \\
\hline 1 . & Belgium-Luxembourg & 21.4 & 20.0 & 13.9 & 22.6 \\
\hline 2 . & Canada & 22.8 & 20.8 & 19.4 & 23.2 \\
\hline 3. & France & 23.4 & 22.7 & 13.4 & 24.8 \\
\hline 4. & Germany & 20.9 & 36.1 & 19.3 & 38.0 \\
\hline 5 . & Italy & 20.8 & 22.2 & 16.6 & 22.3 \\
\hline 6 . & Japan & 30.2 & 27.4 & 14.5 & 31.4 \\
\hline & Netherlands & 20.9 & 28.4 & 14.0 & 28.3 \\
\hline & Sweden & 19.4 & 28.3 & 15.3 & 24.5 \\
\hline & United Kingdom & 18.5 & 20.9 & 14.7 & 25.9 \\
\hline & United States & 18.2 & 18.8 & 16.2 & 17.9 \\
\hline
\end{tabular}

Source: See text.

The most critical assumption may be a constant equilibrium capitaloutput ratio. As the price of other inputs rise relative to the cost of capital, the optimum capital-output ratio in production will rise as capital is substituted for the other inputs. Since 1973 the relative price of energy has risen perhaps fourfold. The relative price of labour has also risen, especially in the continental European countries. The increase in relative prices of energy and labour, would increase the equilibrium capital-output ratios again raising the investment requirements of Table 10.

Moreover, a number of other factors might call for an upward adjustment of our assumed equilibrium capital-output ratio such as a shift towards a relatively greater share of large-scale projects in total investment activity (energy sector being a prime example), an increase in the share of investment directed to environmental protection, and 
competition from some fast-growing LDCs leading to potentially faster rates of structural change, accelerated capital obsolescence and thus increased full-employment capital output ratios. With this in mind the investment requirement projections should be interpreted to represent some kind of minimum alternative consistent with the growth path towards full employment.

At the aggregate level a slight decrease in the investment share in Belgim, Canada, France and Japan is projected. For the United states, the United Kingdam and Italy, there is a minor increase in the investment share. A general conclusion might be that for these countries capital requirement implies more or less stable investment shares out of GDP. For Germany, Netherlands and Sweden the increase in the investment share is most striking. In the case of Germany the estimate may be out of any reasonable projection range. For all countries, the investment-value added ratios in industry are high historically. In the projections, the only country with investment requirements in industry not significantly greater in the projections than during 197578 is the United States. In general, simply filling in the shortfall of investment since 1973 will require high investment ratios during the recovery period.

The investment "requirements" of Table 10 are in a sense minimum estimates, and thus give the most optimistic view of the potential difficulty with capital formation to 1990. If the size of the capital gap has been underestimated, or if events since 1973 have increased optimal capital-output ratios, then the investment requirements should be adjusted upwards. There are several reasons to expect that the Table 10 estimates are, indeed, low. 
IV. A Model for Trade and Exchange Rate Projections

IV. A. Introduction

This paper outlines a model of world trade and exchange rates. The modelling effort was not focused on producing original research in the International trade and financial flelds, but on constructing a calculating machine that would give us reascrable projections of trade volume and exchange rates, given assumptions on alternative development in the OECD economies, developing countries and centrally planned economies. The model covers 26 regions, of which 23 are members of the ORCD. The non-OECD world 18 covered by the last three reglons. The reglons are:

i. Augtralia

2. Austria

3. Belglum-Luxembourg

4. Canada

5. Denmark

6. Finland

7. France

8. Germeny

9. Iceland

10. Ireland

11. Italy

12. Japan

13. Netherlands

\section{Norway}

15. Portugal

16. Spain

17. Sweden

18. Switzerland

19. United Kingdom

20. United States

21. Greece

22. New Zealand

23. Turkey

24. Non-o11 LDCs

25. OPEC

26. Centrally Planned Bconomies

It can be used to project changes in the pattern of international trade in goods and services. The channels through which trade pattern change are relative price changes and differential rates of growth in the donestic economles. These changing patterns of trade w111 have Important consequences for bilateral economic relations and a country's balance of payments position. The model thus allows us to Investigate possible balence of payments difficulties arising from alternative domestic macro projections. Countries cannot Indefinitely maintain large current account deficits or surpluses without experiencing some change in the exchange rate or an impact on the internal balance. The model w11l give Indications of such payments pressure on any of the countries with alternative assumptions of the time paths of exogenous varlables. 
The model is driven by time paths of several macroeconomic varlables and the values of the parameters in the equations forming the model. The list of varlables that control the external sector differ by region. For the 23 OBCD regions the main exogenous varlable 18 real GDP. Other exogenous variables for the OBCD reglons are net labour incomes, net private transfers from abroad and the inftial value of net capital incomes from abroad. For OPEC, Imports of goods and services are exogenous. Also exogenous are the small current account 1tems: the net labour incomes and private transfers. The only difference for the Centrally Planned Economies region is that net capital flow is the main exogenous varlable rather than imports. The treatment of non-o11 IDCB 1s roughly similar to that of OECD countries.

Projections with the model can be carrled out in several alternative modes. First, the model could be used to project developments of current account for each country and region with the assumption of flxed exchange rates. Th1s alternative means projecting world trade with exogenously profected Import market shares, because there are no endogenous changes in relative prices. On the other hand the model lends 1tself easily to analysis of a case of adjustable exchange rates. Thls approach assumes that exchenge rates are adjusted to maintain some target current account balances, and then calculates the necessary changes under the projection assumptions. The calculations use estimates of trade price elasticities to move the trade ohare matrix through time.

The adjustable exchange rate profections are not the same as projections of what would happen with flexible rates. Recently, the theoretical Iiterature has turned to the so-called asset market model of flexible exchange-rate determination in which the key role of the exchange rate is the relative price of national monies rather than national outputs. In this model, short-run stablitity of the forelgn exchange market depends on asset substitution, rather than trade elasticities. Th1s approach has been used to determine the six key exchange rates and these equations are linked to the trade model. We believe that it is important to integrate these on the empirical level in order to study the dynamic stabllity of the exchange rate in the long-run because this 18 one of the key 1 ssues for a flexible exchange rate regime. With this integration the model can be used to analyse outcomes from cholces of different exchange rate regimes. 
IV. B. Model Structure

In the following sectlons 1-7 we outline the model's structure. The appendix gives the list of equations in the model and describes in detall how the empirical estimates for the parameters of the model are obtained. Direct econometric estimation of the model is not tried and we do not provide any new empirical evidence here. Instead we try to exploit current theoretical knowledge and empirical relationships including exlsting trade and exchange rate equations for different countries or more comprehensive trade models used in OECD or IMF. They help us to derive the empirical parameters estimates needed for the model. We have, however, made several adjustments to the existing trade elasticities and to the mathematical forms of equations in order to guarantee plausible longterm properties of the system. Section 8 gives the first projection results and concludes the paper.

\section{Import Equations}

In the import side we distinguish between imports of good and services and petroleum imports. In postulating an import demand function for goods and services we have taken imperfect substitution view of international trade In which domestic and tradeable goods are sufficlently non-substitutable in order to generate finfte price elasticities: The share of real imports of goods and services out of real GDP depends on the relative full employment output gap and relative prices. This type of equation has the property that in the long-run when the economy is on 1 ts full employment output path income elasticity of imports equal unity and the long-run import/GDP ratio is constant if relative prices remain unchanged. We have aggregated imports of goods and services, because very few elasticity estinates for services are avallable and because in many cases it is plausible to assume that services Import flows and goods import flows are closely related. This type of equation is applied to all OECD countries. Petroleum Imports are related to real GDP and relative price of petroleum (GDP prices divided by oll prices) for all importing regions. For non-o1l LDCs the volume of imports is decomposed into two parts: an exogenously projected component 
(which is equal to their real GDP growth) and a component which reacts to changes in IDCs import prices relative to their GDP prices. For Centrally Planned Bcononies value of total imports is a residual item In the current account equation.

\section{Export Equat1on}

For our export block we have taken a market share approach. Given est1mates of each country's Imports by equations described above, exports of each country can be determined through import market share matrices. The market share approach 18 applied to the determination of exports of goods and o1l. Services are treated differently, because we do not have the necessary data for bilateral services flows.

The question 18 how best to obtain projectlons for the share matrix, because market shares vary over time due to changes in relative competitiveness whlch can result from changes in relative prices or other factors such as export promotion, delivery times etc. In the model import market shares of goods are assumed to respond to changes in relative prices and to relative non-price competitiveness meesured by the growth of the exporting country's potential output relative to a welghted average of the growth of its competitor's potential output, 1.e. countries with rapidly expanding capacity relative to others are assumed to capture markets. Changes in oll import shares are determined exogenously.

For exports of services we assume that there is a single international trade pool of services to which all exports are delivered. The relative change in each country's share depends on the relative change in its export price relative to the "world price" of services and on the relative change in 1ts potential GDP relative to a weighted average (service export shares as weights) of the relative change in 1ts competitors potential GDP. The relative output terms stands for non-price competitiveness as in the case of goods warket share equation: 


\section{Export Prices}

With the assumption of imperfect competition in international markets the supply function of exports should be specified as some type of pricesetting behavlour. For a small country with no market power in the export markets, the price of exports would be given in forelgn currency. If the country has some market power Its exports prices change less than competitors' prices or costs of production cam be passed to 1 ts export prices to a certain extent. Assuming constant price elasticities of export supply and demand the relative change in export prices can be expressed as a weighted average of the relative change in competitors' prices and the relative change in a varlable measuring domestic cost developments. We have approximated this cost variable by domestic price level. This 18 carried out for later purposes in order to integrate domestic prices into the model.

The relevant measure for the competitor's price variable is a doubly welghted export price Index of country I's competitors in the export markets. First a competitor's price for the country 1 on the $f^{\prime}$ th market is calculated as a welghted average of all other supplier's price on that market. Then these indices are again weighted, the relevant welghts being shares of exports of the country in question to each market country. The competitor's price in service export price equation reduces to a common "world price." This type of equation is applied in the model to determination of the export prices of goods and services. Price of petroleum 1s treated exogenously. It is one of the key input variables of interest in the model.

\section{Import Prices}

Given the determination of export prices, Import prices for each region In the model cam be easily determined as weighted averages of these export prices with market shares as weights. This applies to import prices of goods and petroleum where the weights to be used are import shares of

goods and petroleum respectively. For services we have a common world price equation where the welghts are world trade shares of services of each country. 
5. Qurrent Account Equation

In order to obtain current account equations for each region, the determination of ald flows, factor incones and net private transfers in the current account are needed. The total amount of ald recelved by non-oll IDCs is profected exogenously. The inerease in total ald flow is allocated between donor countries according to constant 1975 shares. Net interest Incomes from abroad are generated as a multiple of "world interest rate," exogenous to the model, and cumulated current account of each country.

Other terms in the current account, 1.e., net private transfers and net labor incomes from abrosd are determined exogenously outside the model. Finally we have a current account equation for each region. For centrally planned economieg current account balance is fixed outside the model and the value of Imports is the adfusting Item, 1.e., we assume that this region uses all its foreign currency recelpts to buy imports. All the building blocks of the model are constructed in way which autonatically takes Into account the world trade balance and current account constraints.

6. The Effect of Import Prices on the Domest1c Price Level

There are several ways through which the domestic price level can be affected by international price developments. First, domestic prices may be changed if there is substitution between tradeable and domestically produced goods. Price effects from the tradeable goods sector can a also channel through labour markets to the prices of non-tradeable goods. In addition, the abosption of external inflationary pressures may happen through prices of imported raw materials and petroleun, which calls for a formulation of a cost-push model. Here we limit ourselves only to the latter approach. At this stage we also ignore inflation coming from domestic developments. $1 /$ Thus in the model variation in the domestic price level comes through changes in import prices of goods and petroleum. It should be noted here that we have assumed no change in relative prices between traded final and intermediate goods, and that 1s why Import price of goods (excluding oll) serves as a proxy for import price of raw materials in the domeatic price equation. This naturally means that the model shows only the inflatlonary effect of the pressure coming from import price increases. Nevertheless, it adds one important link to the model and thus provides a more plausible approximation of reality than a purely exogenous treatment of the domestic price level.

I/The work is in progress to capture effects of different money growth rates on inflation rates and exchange rates. 


\section{Exchange Rate Block}

From the early 1970s onwards countries adopted a wide variety of exchange rate syetems. Mafor ORCD countrles have had more or less floating exchange rates since 1973 while several small OECD economies and developing countries chose to peg their currencies to some basket or a single currency. $\underline{\text { / }}$

We have tried to capture some basic lines of the present policy $2 /$ : the currencles of the $\mathrm{blg}$ seven OBCD countries are floating, smaller OECD countrles and developing countrles peg their currencles in an adjustable way to a trade welghted basket; o11 trade and Centrally Planned Economles' trade with the rest of the world is in dollars. With the Integration of exchange rate equations into trade model, it can be used to analyse outcomes from choices of different exchange rate regimes.

The trade block of the model generates projections for the current account. The link from the current account to the exchange rate for floaters 1s obtalned by applying the asset market approach (see e.g. Branson, 1977) to determine (dollar/local currency) exchange rates for Canada, Prance Germany, Italy, Japan and the Onited Ringdom. W1th flexible exchange rates the sum of balances on capital account and current account for these countries is Identically zero (central bank foreign reserves stay constant). If the current account shows a surplus, the capital account remains in deficit and the private sector accumulates foreign assets. According to our equations this moves the exchange rates in the short run. Changes in the exchange rates w111 affect trade flows and change the current account which in turn woves the exchange rate. In the model, a current account deficit (surplus) of country 1 will cause its currency to depreclate (appreclate). Th1s in turn improves (worsens) the current account. The long-run dynamic adjugtment thus happens through the interaction of exchange rate equations and the trade block. The effect of the exchange rate movement on trade takes time and enough time must pass to bring the current account to zero. However, in the projectlons we would not necessarily expect to see balanced current accounts as exports and imports are moved through growth rates of GDP which may differ from country to country. Smaller OECD countries and non-011 LDCs peg their currencles to a trade wolghted basket in an adjustable

1/ Branson and Papaefstlatiou (1978) offer an extensive discussion of criterla of choosing an exchange rate regime, see also Heller (1976).

2/ The major drawback here may be that the present EMS 18 not modelled. This is an important topic to be integrated into the model. 
way. The value of country i's currency against its trading partners' currencies is changed according to a criterla which says that country $i$ is devaluing (revaluing) its currency against other currencies when it is running a current account deficit (surplus) by a certain amount of its relative (current account over value of exports) current account deficit (surplus). The devaluation (revaluation) percentage is, however, dependent on last period's policy: if a country devalued (revalued) last period and if it is still running a deficit (surplus) this period's devalution (revaluation) percentage will be smaller.

IV. C. Trade and Exchange Rate Projections

This section compares three simulations with the trade-exchange rate model described above. The simulations were designed to illustrate the flexibility of the model and the type of information it generates. 1

\section{Exogenous Inputs}

For these simulations it is assumed that GDP follows the path described in section II for the twenty OECD countries. For Greece, New Zealand, Turkey, the non-oil LDC's, OPEC, and the CPE's, the GDP growth rate is arbitrarily set. The aid inflow to the LDC's is taken from World Bank 1976 SIMLINK projections. The capital inflow to the CPE's declines steadily from its 1976 value to zero by 1990. The final exogenous time series are the price of oil and OPEC imports. For these runs we set the ofl price index equal to the actual for 1975 through 1979 (as of July 1980) and to the 1979 value for 1981 through 1990. The OPEC imports are equal to actual from 1975 through 1979 and then increase so that OPEC has a zero balance on current account by 1990.

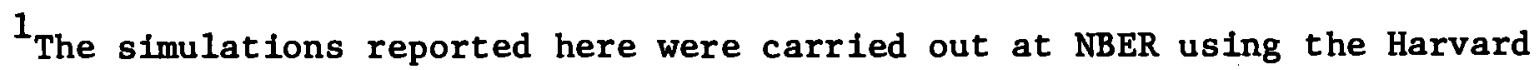
Computing Center's ITEL/AS5 with a Fortran program written by Dennis Warner. 
The Three Simulations

Three simulations are compared here. First a flexible exchange rate simulation is compared with a fixed exchange rate simulation. The fixed-rate simulation is of no interest in itself. It is useful only in that it allows an illustration of the importance of the flexible-rate model. The third simulation is a flexible-rate run with an exogenous increase in Germany's rate of growth of actual GDP. The comparison between this and the original flexible rate run is meant to illustrate some aspects of the importance of Germany as a "locomotive" in pulling the European train toward potential output paths.

The Standard Simulation

Tables 11 and 12 display some results from the standard flexibleexchange rate run. The figures in Table 11 show differences between the flexible rate and fixed exchange rate simulations. In this table the cumulative current account figures show that impossibly large net foreign asset positions would result if exchange rates were fixed. Germany, Italy, the U.K., and the U.S. would accumulate very large net foreign assets without flexible rates while the LDC's and several smaller OECD countries would have huge net liabilities. In general, the fastest growing countries (the LDC's and the smaller OECD countries), are forced to depreciate to reduce their foreign liabilities while the relatively slow-growing major OECD countries appreciate and decrease their foreign assets compared to a fixed rate regime.

Table 11 shows also the changes in export market penetration caused by the flexible exchange rate system. Countries which depreciate gain market share and conversely for the appreciating countries. 
TABLE 11

Changes Caused by Flexible Exchange Rates

\begin{tabular}{|c|c|c|c|c|c|c|}
\hline & & E Worlo & & & Lative Cu & \\
\hline & & is Exp & & & Account & \\
\hline & 79 & 85 & 90 & 79 & 85 & 90 \\
\hline Canada & .1 & .1 & -.1 & -6.2 & -29.2 & -52.0 \\
\hline France & .2 & .5 & .4 & -2.6 & 9.0 & 20.6 \\
\hline Germany & -.4 & -.4 & -.1 & -17.6 & -78.2 & -137.9 \\
\hline Italy & .0 & -.4 & -.6 & -4.8 & -58.0 & -168.9 \\
\hline Japan & -1.2 & $-1 \cdot 3$ & -1.2 & -36.2 & -183.6 & -383.3 \\
\hline U.K. & -.4 & -1.3 & -1.5 & -11.4 & -112.1 & -288.3 \\
\hline U.S. & -.6 & -1.0 & -1.0 & -33.7 & -180.9 & -406.5 \\
\hline LDCs & 2.9 & 3.5 & 2.9 & 94.9 & 465.7 & 884.7 \\
\hline OPEC & -.5 & -.6 & -.6 & .3 & 18.0 & 61.6 \\
\hline CPEs & -.1 & -.3 & -.4 & -.3 & -1.1 & -1.4 \\
\hline Australia & .0 & .0 & -.1 & -.4 & -6.3 & -15.9 \\
\hline Austria & .0 & .1 & .1 & .9 & 4.4 & 14.0 \\
\hline Belgium & .1 & .0 & .0 & -2.9 & -14.5 & -19.5 \\
\hline Denmark & .0 & .1 & .1 & 3.0 & 22.3 & 55.0 \\
\hline Finland & .0 & .2 & .2 & 1.5 & 13.4 & 36.0 \\
\hline Iceland & .0 & .0 & .0 & .1 & .1 & .6 \\
\hline Ireland & .0 & .0 & .1 & .5 & 8.3 & 26.6 \\
\hline Netherlands & -.1 & -.1 & .1 & -6.5 & -31.4 & -35.5 \\
\hline Norway & .1 & .1 & .0 & 10.7 & 116.4 & 91.5 \\
\hline Portugal & .1 & .2 & .4 & 1.3 & 13.6 & 36.9 \\
\hline Spain & .1 & .2 & .3 & 8.6 & 54.4 & 132.2 \\
\hline Sweden & .1 & .1 & .2 & 2.7 & 28.6 & 74.9 \\
\hline Switzerland & -.2 & -.2 & .0 & 11.3 & -42.6 & -77.2 \\
\hline Greece & .1 & .1 & .2 & 2.8 & 14.6 & 53.0 \\
\hline New Zealand & .1 & .1 & .1 & 2.3 & 9.6 & 18.0 \\
\hline Turkey & .1 & .3 & .5 & 4.1 & 29.4 & 80.5 \\
\hline
\end{tabular}


$\underline{\text { TABLE } 12}$

\begin{tabular}{|c|c|c|c|c|c|c|c|c|c|c|c|}
\hline & \multicolumn{3}{|c|}{$\begin{array}{l}\text { Rea1 Exchange }{ }^{1} \\
\text { Rate } \\
(1975=100)\end{array}$} & \multicolumn{3}{|c|}{$\begin{array}{c}\begin{array}{c}\text { World Market } \\
\text { Share }\end{array} \\
\end{array}$} & \multicolumn{3}{|c|}{$\begin{array}{r}\text { Balance on } \\
\text { Petroleum } \\
\end{array}$} & \multicolumn{2}{|c|}{ Inflation } \\
\hline & 1979 & 1985 & 1990 & 1979 & 1985 & $1990_{1}$ & 1978 & 1985 & 1990 & 3 & 4 \\
\hline 1. Canada & 106 & 112 & 113 & 4.5 & 3.8 & 3.4 & 1.4 & .8 & .9 & .1 & .0 \\
\hline 2. France & 95 & 86 & 86 & 7.4 & 7.9 & 7.6 & -20.3 & -25.3 & -28.4 & .2 & .4 \\
\hline 3. Germany & 109 & 105 & 102 & 11.5 & 11.7 & 11.3 & -16.9 & -21.9 & -24.2 & .1 & .1 \\
\hline 4. Italy & 105 & 117 & 120 & 4.4 & 4.4 & 4.4 & -14.0 & -18.4 & -21.7 & .3 & -.4 \\
\hline 5. Japan & 116 & 119 & 121 & 9.0 & 9.8 & 10.7 & -34.5 & -46.1 & $-56 . .6$ & .3 & .0 \\
\hline 6. United Kingdom & 108 & 133 & 137 & 5.4 & 4.5 & 3.8 & -2.9 & .0 & .3 & .2 & -.6 \\
\hline 7. United States & 106 & 113 & 117 & 14.2 & 12.2 & 11.1 & -25.8 & -23.1 & -25.1 & .1 & .0 \\
\hline 8. LDCs & 71 & 71 & 76 & 14.0 & 15.2 & 15.5 & 4.0 & 2.6 & 2.9 & .0 & .0 \\
\hline 9. OPEC & 105 & 112 & 116 & 4.1 & 4.3 & 4.8 & 150.7 & 188.4 & 277.0 & - & - \\
\hline 10. CPEs & 105 & 112 & 116 & 4.0 & 4.2 & 4.5 & 3.7 & 4.1 & 4.6 & - & - \\
\hline 11. Australia & 96 & 104 & 108 & 1.7 & 1.7 & 1.7 & -.7 & -.8 & -.9 & .1 & .0 \\
\hline 12. Austria & 99 & 96 & 92 & 1.1 & 1.2 & 1.2 & $-1 \cdot 3$ & -1.9 & -2.2 & .1 & .3 \\
\hline 13. Belgium-Lux. & 109 & 105 & 97 & 4.1 & 4.0 & 3.8 & -4.9 & -6.5 & -7.3 & .2 & .5 \\
\hline 14. Denmark & 87 & 72 & 67 & 1.1 & 1.1 & 1.0 & -2.4 & -3.2 & -3.5 & .1 & 1.0 \\
\hline 15. Finland & 73 & 50 & 42 & .8 & .9 & .9 & -2.4 & -3.2 & -3.6 & .2 & 2.2 \\
\hline 16. Iceland & 90 & 87 & 84 & .0 & .0 & .0 & .0 & .0 & .0 & .0 & .6 \\
\hline 17. Ireland & 100 & 96 & 91 & .4 & .4 & .5 & -.4 & -.5 & -.6 & .1 & .8 \\
\hline 18. Netherlands & 114 & 106 & 96 & 5.0 & 5.3 & 5.4 & -72.2 & -17.5 & -20.1 & .3 & .6 \\
\hline 19. Norway & 76 & 73 & 72 & 1.0 & .9 & .8 & .0 & .0 & .0 & .0 & .8 \\
\hline 20. Portugal & 71 & 42 & 34 & .3 & .5 & .7 & -1.1 & -1.4 & -1.6 & .3 & 3.7 \\
\hline 21. Spain & 86 & 71 & 70 & 1.3 & 1.5 & 1.7 & -8.8 & -12.0 & -14.4 & .3 & .9 \\
\hline 22. Sweden & 85 & 63 & 56 & 2.2 & 2.0 & 1.9 & -5.7 & -8.0 & -8.5 & .1 & 1.0 \\
\hline 23. Switzerland & 126 & 119 & 110 & 1.6 & 1.5 & 1.6 & -.7 & -.9 & -1.0 & .1 & -.2 \\
\hline 24. Greece & 96 & 82 & 75 & .4 & .4 & .5 & -1.6 & -1.9 & -2.2 & .5 & 1.7 \\
\hline 25. New Zealand & 69 & 70 & 73 & .4 & .4 & .4 & -.3 & -.4 & -.4 & .1 & .3 \\
\hline 26. Turkey & 63 & 37 & 28 & .4 & .6 & .8 & -2.3 & -3.0 & -3.4 & .1 & 1.8 \\
\hline
\end{tabular}

1. Index of ratio of US $\$$ denominated GDP deflator to total trade weighted average of trading partners US \$ denominated GDP deflators, 1975=100.

2. Share of total world non-oil goods exports 1975 US \$ denominated prices.

3. Increase in average annual inflation rate due to oil price increase.

4. Increase in average annual inflation rate due to exchange rate changes. 
Table 12 gives further results for the standard flexible rate simulation; the real exchange rates, world market shares, balance on petroleum, and incremental inflation rates. All of the large OECD countries, except France, and OPEC, CPES, Australia, and Switzerland have an increased real exchange rate at the end of the simulation while the rest depreciate to varying degrees.

Under a fixed exchange rate regime with high growth, the largest gainers in world market shares are the fast growing countries; at the top of the 11st come Japan, OPEC and other LDC's. At the other end slow growing "mature" OECD countries such as the United States, Canada, the United Kingdom, Switzerland, Belgium, the Netherlands and Scandinavian countries are losing markets. These changes are due to two types of effects. They can happen through market growth depending on whether countries are exporting to the fast or slow growing markets or through distribution effect: in the model a country with higher growth of capacity output relative to that of its competitors means that the country in question is capturing markets.

The balance of payments difficulties arising from different growth rates of outputs under fixed exchange rate regimes imply potential pressures on countries' exchange rates or on internal balance in the longer run. The flexible exchange rate run produces one possibility to look at the pressures on exchange rates of different countries and also to look at the consequences of this on the market shares of different countries through changes in relative price competitiveness. The projection shows the orders of magnitudes of these changes (see real exchange rate column in Table 12). Japan, German, the Netherlands, Switzerland, Belgium, and the United Kingdom are appreciating their currencies in real terms mostly due to a tendency to run current account surpluses under fixed exchange rates. Surpluses and thus appreciation would occur, however, for different reasons. 
Fast growing Japan is capturing markets but it also exports a remarkable share to fast growing markets of LDC's. The latter is also true for Germany being among major exporters to developing countries. The United Kingdom's surplus is generated mainly due to slowly growing import demand but also to fast growing markets for their exports in LDC's. The appreciation is also reflected in market shares: in general, appreciating countries are losing markets due to the weakening of their price competitiveness when compared to the projection under the regime of fixed exchange rates. Scandinavian countries, Mediterranean countries and non-oil LDC's are devaluing their currencies in real terms as a consequence of running current account deficits with fixed exchange rates. This is increasing their shares of world markets from what they would be under the assumption of fixed exchange rates.

It should be noted here that the good export performance of Japan and non-oil LDC's in the model is due to different reasons. Japan's success comes from a better non-price competitiveness measured by relative growth of capacity output (i.e., expanding productive capacity is assumed to be linked with rapid introduction of technological innovation, intensified export promotion, etc.), while at the same time Japan is experiencing losses due to the appreciating yen. In the case of non-oil LDC's, both better price and non-price competitiveness are helping to increase market share. The channel through increase price-competitiveness due to a large devaluation of LDC's currencies is much more important as indicated by comparison between flxed and flexible exchange rate runs of Table 11; under fixed rate assumptions non-oil LDC's world market shares increase from 11.1 percent in 1979 to 12.6 percent in 1990 but jumps 4.4 percentage points from this to 15.5 percent due to the introduction of the flexible exchange rate regime. It is obvious that the flexible exchange rate run overestimates non-oil LDC's share. 
The final columns in Table 13 show the incremental inflation rates. Since there is no money growth or excess demand for goods in this model there are only two causes for an increase in the domestic GDP deflators: exogenous oil price increases and exchange rate changes. The first of the two columns shows the average increase in the inflation rate due to the exogenous oil price increase while the second gives the changes in inflation rates due to changes of exchange rates. For the appreciating countries there are deflationary pressures while for depreciating countries there are inflationary pressures. The effects of exchange rate movements on the domestic price level are more pronounced for the smaller and more open economies.

\section{Higher Growth in Germany}

For this simulation it was assumed that Germany's growth rate of output was, on average, one percentage point higher than in the standard run. Here we compare the results of the two simulations to illustrate some of the crosscountry linkages present in the model.

Due to the higher growth Germany's current account is lowered (see Table 13) and its real exchange rate depreciates by $23 \%$ by 1990 . This depreciation lowers the relative price of German exports, giving it an additional $1.4 \%$ of the world's non-oil goods market by 1990 and causing a $0.4 \%$ increase in the average domestic inflation rate.

The countries affected most strongly are France, Italy, the United Kingdom, Belgium, and the Netherlands. For all countries there are two primary channels of influence; the exchange rate determination system and the current account. France's, Italy's, and the U.K.'s exchange rates are linked directly to Germany's current account. Initially Germany's current account worsens due to higher import demand, while theirs improves because of higher 
TABLE 13

Changes Caused by Increased German Growth

Shares of World Non-oil Goods Exports $1979 \quad 1985 \quad 1990$

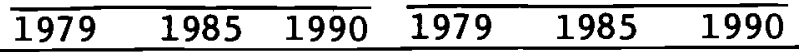

Cumulative Inflation Rate

\begin{tabular}{|c|c|c|c|c|c|c|c|c|c|c|}
\hline 1. Canada & .0 & -.1 & .0 & .0 & -1.1 & .1 & .1 & .2 & .1 & .0 \\
\hline 2. France & .0 & -.2 & -.4 & .3 & 9.6 & 13.3 & -.2 & -6.7 & -5.3 & -.3 \\
\hline 3. Germany & .0 & .9 & 1.4 & -.6 & -15.6 & -23.1 & -.7 & -38.1 & -57.2 & .4 \\
\hline 4. Italy & -.1 & -.1 & .0 & .7 & 12.7 & 8.8 & -.2 & -20.1 & -55.7 & .0 \\
\hline 5. Japan & .0 & -.2 & -.2 & .0 & -.9 & -.8 & .2 & 1.7 & 1.7 & -.2 \\
\hline 6. United Kingdom & -.1 & -.1 & -.1 & .5 & 10.4 & 14.1 & -.2 & -9.0 & -19.1 & -.1 \\
\hline 7. United States & .0 & -.2 & -.3 & -.1 & -.8 & -.4 & .4 & 3.5 & 4.2 & .0 \\
\hline 8. LDCs & .0 & -.3 & -.4 & .0 & 1.4 & 2.1 & .2 & 8.6 & 8.6 & -.1 \\
\hline 9. OPEC & .0 & -.1 & -.1 & .0 & -.8 & -.4 & .2 & 12.2 & 47.0 & - \\
\hline 10. CPEs & .0 & .0 & -.1 & .0 & -.8 & -.4 & .0 & .5 & .6 & - \\
\hline 11. Australia & .0 & -.1 & .0 & .0 & -.4 & -.4 & .0 & -.3 & -.4 & .0 \\
\hline 12. Austria & .0 & .0 & .0 & .2 & .2 & 2.6 & .1 & 2.5 & 4.9 & -.2 \\
\hline 13. Belgium-Lux. & .0 & .1 & .1 & -.1 & 1.9 & 4.6 & .2 & 5.1 & 10.0 & -.3 \\
\hline 14. Denmark & .0 & .0 & .0 & .0 & 1.9 & 3.9 & .0 & 2.1 & 4.1 & -.2 \\
\hline 15. Finland & .0 & .0 & .0 & .0 & 2.2 & 3.8 & .1 & 2.1 & 4.7 & -.2 \\
\hline 16. Iceland & .0 & .0 & .0 & .0 & 1.4 & 2.4 & .0 & .1 & .0 & -.2 \\
\hline 17. Ireland & .0 & .0 & .0 & .2 & 2.2 & 2.0 & .0 & -.2 & -.5 & -.1 \\
\hline 18. Netherlands & .0 & .2 & .0 & -.1 & 2.1 & 4.9 & .4 & 10.0 & 19.5 & -.3 \\
\hline 19. Norway & .0 & .0 & .0 & .0 & 1.3 & 2.3 & .0 & .5 & .7 & -.1 \\
\hline 20. Portugal & .0 & .1 & .0 & .1 & 2.7 & 4.0 & .0 & 2.1 & 5.1 & -.3 \\
\hline 21. Spain & .0 & .1 & .0 & .1 & 2.7 & 3.5 & .0 & 2.6 & 2.9 & -.2 \\
\hline 22. Sweden & .0 & .1 & .1 & .0 & 2.5 & 4.3 & .0 & 3.4 & 6.3 & -.1 \\
\hline 23. Switzerland & .0 & .0 & .0 & .0 & 1.9 & 2.3 & .0 & 1.1 & 1.7 & .0 \\
\hline 24. Greece & .0 & .0 & .0 & .0 & .9 & 1.3 & .1 & .9 & 1.6 & -.2 \\
\hline 25. New Zealand & .0 & .0 & .0 & .0 & 1.5 & 2.0 & .0 & .2 & .1 & .0 \\
\hline 26. Turkey & .0 & .0 & .0 & .0 & 1.8 & 2.6 & .0 & 1.8 & 4.1 & -.1 \\
\hline
\end{tabular}


exports to Germany. This causes France's, Italy's and the U.N.'s exchange rates to appreciate and Germany's to depreciate. In the longer run the appreciation of the three currencies outweigh the direct stimulus from Germany's import demand and the current accounts weaken. All three lose market shares and experience a decline in their inflation rates.

For the smaller European countries the effects are somewhat different. With the exception of Ireland, whose exchange rate is closely linked to the U.K.'s, all experience an improved trade, and, hence, current account balance because of increased German demand. All of their exchange rates appreciate slightly and their inflation rates are lowered. Here it must be remembered that output is always kept at an exogenous level so there is no labor market pressure on costs, only pressure from the change in prices of imported goods. The effects on the non-European countries are relatively smal1. OPEC does experience a significant increase in its current account due to increased oil exports to Germany. The effects on Canada, Japan, the U.S., Australia, and New Zealand are very small. 